\title{
Changes in Viability and Microflora of Soybean Seeds Stored under Various Conditions in Puerto Rico ${ }^{1,2}$
}

\author{
F. D. Tenne, E. J. Ravalo, J. B. Sinclair, and E. D. Rodda ${ }^{3}$
}

\begin{abstract}
Woodworth soybean (Glycine max) seed lots were stored under tropical conditions at two locations of the University of Puerto Rico, in four types of containers at three moisture levels, arranged in a completely randomized factorial design. Germination overall factors decreased with time. Germination decreased with increased length of storage and was accompanied by a concomitant increase in the occurrence of Bacillus subtilis. After 9 mo, the seeds with an initial moisture content (dry basis) of $8.6 \%$ had a higher germination and lower occurrence of seed-borne microorganisms than those stored with $10.7 \%$ and $12.5 \%$. Seeds stored in 200-g sealed food cans maintained germination longer than those stored in nonsealed cans with a plastic lining, plastic-lined fertilizer bags, or in cloth bags. Seeds stored in cloth bags had a greater incidence of $B$. subtifis than those from the other storage containers. Whether or not there were significant differences between storage location for any main effects or interactions depended upon the parameter measured.
\end{abstract}

\section{INTRODUCTION}

Soybean (Glycine $\max (\mathrm{L}$.) Merr.) seed viability measured by in vitro germination is reduced by storage in temperate regions by several factors, including microorganisms $(7,9,10,11,13,14,17)$, temperature $(1,13)$, moisture level $(8,10,13)$, field history before harvest (7), and storage container (8).

Kennedy (9), Ramstad and Geddes (10), and Tervet (17) reported the association of Aspergillus spp. with reduced viability of soybean seeds in storage. Penicillium spp. also was found to invade soybean seeds (7). Tedia (13) showed that the microorganisms most frequently associated with the decline in vigor of soybean seeds stored at high temperature $\left(35^{\circ} \mathrm{C}\right)$ and moisture (13\%) were Aspergillus spp. and Bacillus subtilis. $B$. subtilis has been shown to be seed-borne in soybean (15). Soybean seed viability decreases with increased moisture levels from $9.4 \%$ to $19.1 \%$ at room temperature (10).

${ }^{1}$ Manuscript submitted to Editorial Board December 5, 1977.

${ }^{2}$ This report covers work conducted cooperatively between the College of Agriculture of the Universities of Illinois, Urbana-Champaign, and of Puerto Rico, Mayagüez, through the International Soybean Research Program (INTSOY) and is a portion of the senior author's Ph.D. thesis. It was supported in part by the Illinois Agricultural Experiment Station.

${ }^{3}$ Former Research Associate of Plant Pathology, Assistant Professor of Agricultural Engineering, Professor of Plant Pathology, and Professor of Agricultural Engineering, respectively. The first, third and fourth authors are employed by the University of Illinois, Urbana, and the second author by the University of Puerto Rico, Mayagüez. 
Baciu (1) showed that soybean seeds stored in glass containers sealed with paraffin or in double polyethylene bags at 10 to $13^{\circ} \mathrm{C}$ had higher germination and seedling vigor than seeds stored in more air- and moisture-permeable containers. He concluded that this was due to fluctuations in seed moisture. Harrington (8) found that the storage of seeds at low moisture levels in moisture-proof packages prolonged seed viability.

The effect of various containers and storage conditions on viability and on the microorganisms associated with soybean seeds is reported in this paper. The work was carried out under tropical conditions at the University of Puerto Rico, Mayagüez (UPRM) and at the agricultural experiment substantion in Isabela.

SEED STORAGE EXPERIMENTAL DESIGN

LOCATION
Mayagüez Isabela
STORAGE CONDITIONS
Ambient Insulated
CONTAINERS
C1 C2 C3 C4
MOISTURE CONTENTS
$8.6 \% \quad 10.7 \% \quad 12.5 \%$
STORAGE PERIODS
3 months 6 months 9 months
REPLICATIONS
$1 \quad 2 \quad 3$

Frg. 1.-Experimental design for storage experiment conducted in Puerto Rico at the Mayagüez Campus and the Agricultural Experimental Substation in Isabela. $\mathrm{CI}=$ sealed metal can; $\mathrm{C} 2=$ metal can with plastic lining (not sealed); $\mathrm{C} 3=$ fertilizer bag with plastic lining; and $\mathrm{C} 4=$ cloth bag. $\mathrm{MCDB}=$ moisture content dry basis.

\section{MATERIALS AND METHODS}

The study was designed for factorial analysis, using 432 200-g samples to determine the effect of three levels of seed moisture $(8.6,10.7$, and $12.5 \%$ dry basis), four storage containers (a sealed 200-g metal food can, a nonsealed can with 1 mil plastic lining, a fertilizer bag with 1 mil plastic lining, or a cloth bag), two storage conditions (open shelves or packed in rice hulls in cardboard containers), and three storage times $(3,6$, or $9 \mathrm{mo})$ (14). There were 144 samples for each storage time (fig. 1).

Two kinds of assays were made on each seed lot after each storage period. All seeds were surface disinfected by soaking in $0.5 \%$ sodium hypochlorite $(\text { Clorox })^{4}$ for $4 \mathrm{~min}, 70 \%$ ethanol for $2 \mathrm{~min}$, and rinsed in

${ }^{4}$ Trade names are used in this publication solely for the purpose of providing specific information. Mention of a trade name does not constitute a guarantee or warranty of equipment or materials by the Agricultural Experiment Station of the University of Puerto Rico or an endorsement over other equipment or materials not mentioned. 
sterile distilled water for $1 \mathrm{~min}$ before assaying. First, 50 seeds per sample were assayed by placing five seeds in each $9-\mathrm{cm}$ culture plate containing commercial (Difco) potato-dextrose agar (PDA) and incubated for 6 days at $25^{\circ} \mathrm{C}$. Second, 25 seeds per sample were placed on moist cellulose (Kimpac) pads in a seed germinator for 6 days at $35^{\circ} \mathrm{C}$. The percentage germination and occurrence of fungi and $B$. subtilis associated with germinated and nongerminated seeds were recorded for both assays. A seed was considered germinated when the radicle was twice the length of the cotyledons.

One hundred randomly selected $B$. subtilis colony types were obtained in pure culture from the two assays. The reactions of 25 of these cultures

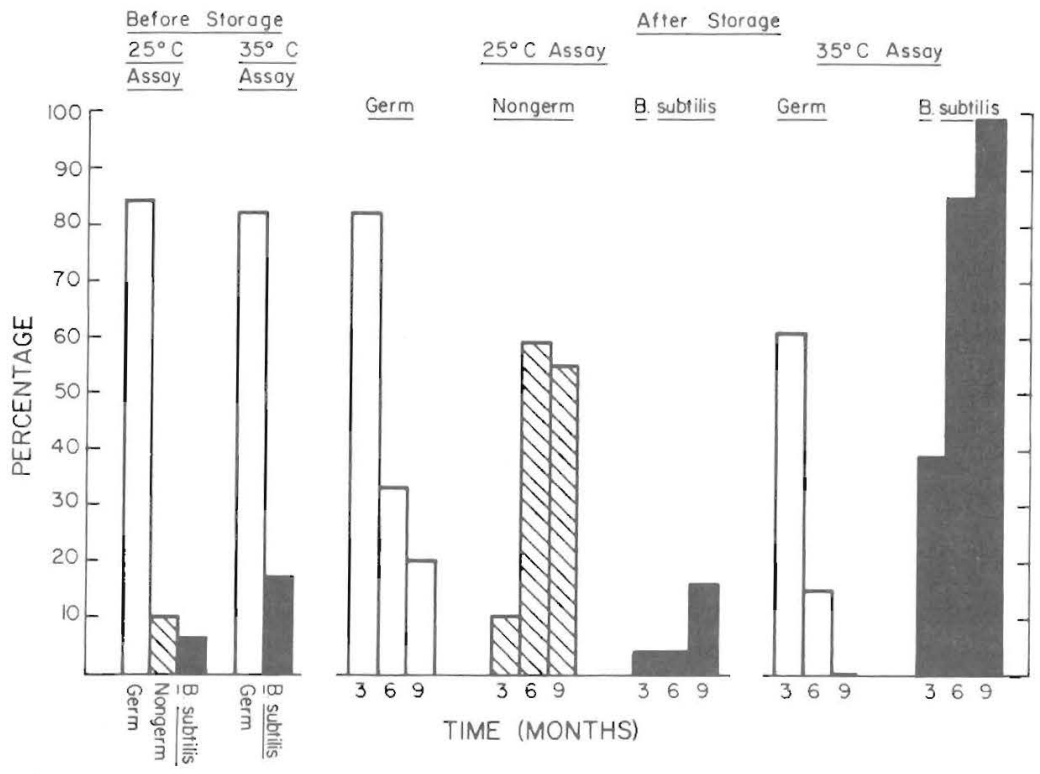

FIG. 2.-Mean percentage germination, nongermination, and occurrence of Bacillus subtilis from Woodworth soybean seeds assayed after harvest at 25 and $35^{\circ} \mathrm{C}$ after 3,6 , or 9 mo storage in Puerto Rico.

were compared to the American Type Culture Collection isolate No. 6051 of $B$. subtilis, using the following standard microbiological tests as described in Bergey's Manual of Determinative Bacteriology (2): Gram stain, catalase reaction; growth on ammonium-yeast-mannitol agar, starch agar, tyrosine agar, gelatin agar, nitrate and glucose broth (anaerobically and aerobically), $7 \% \mathrm{NaCl}$ broth, acetyl methylcarbinol broth, nutrient agar, glucose agar, and soybean agar; growth on Sabourad dextrose agar; growth in nutrient broth; growth in $1 \%$ glucose nutrient agar stab; acid production and utilization of arabinose, xylose, and mannitol; litmus milk reaction; alkali on citrate salt agar; $\mathrm{pH}$ of glucose broth 

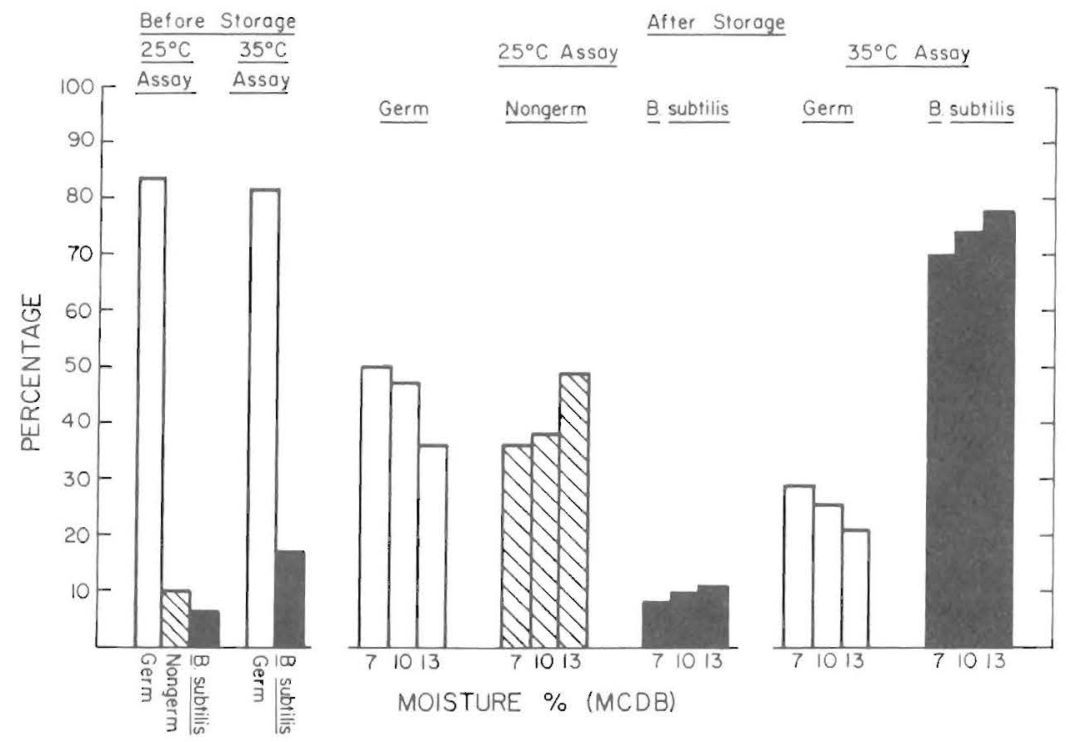

FIG. 3.-Mean percentage germination, nongermination, and occurrence of Bacillus subtilis from Woodworth soybean seeds assayed after harvest at 25 and $35^{\circ} \mathrm{C}$ after $9 \mathrm{mo}$ storage for seeds stored initially at 7,10 , and $13 \%$ moisture content dry basis at ambient conditions in Puerto Rico.

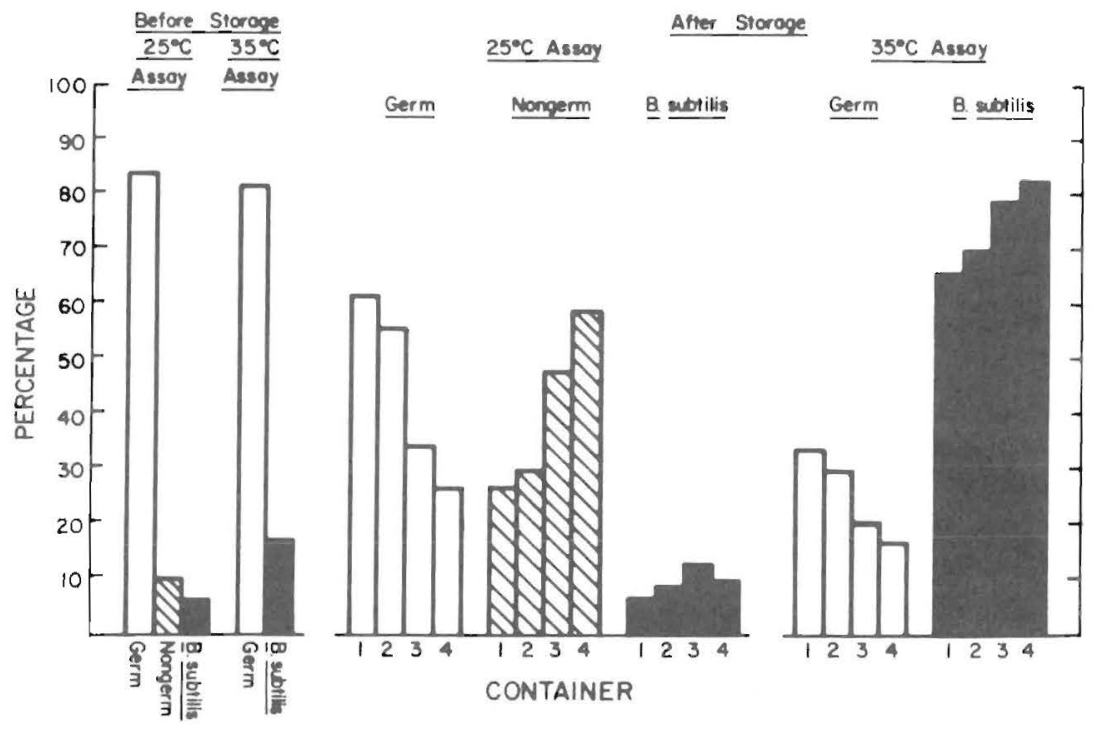

FIG. 4.-Mean percentage germination, nongermination, and occurrence of Bacillus subtilis from Woodworth soybean seeds assayed in Puerto Rico after harvest at 25 and $35^{\circ}$ $\mathrm{C}$ before and after 9 mo storage in the containers of: 1) sealed metal can; 2) unsealed metal can with plastic lining; 3) fertilizer bag; and 4) cloth bag. 
cultures; and size of cells and spore production. All isolates from the affected soybean seeds reacted identically to the ATCC isolate of $B$. subtilis.

\section{RESULTS}

The nontreated (not stored) seed lots assayed on PDA germinated $84 \%$. Ten percent of the nongerminated seeds contained no microorganisms and $6 \%$ contained $B$. subtilis. Seed placed on cellulose pads ger-

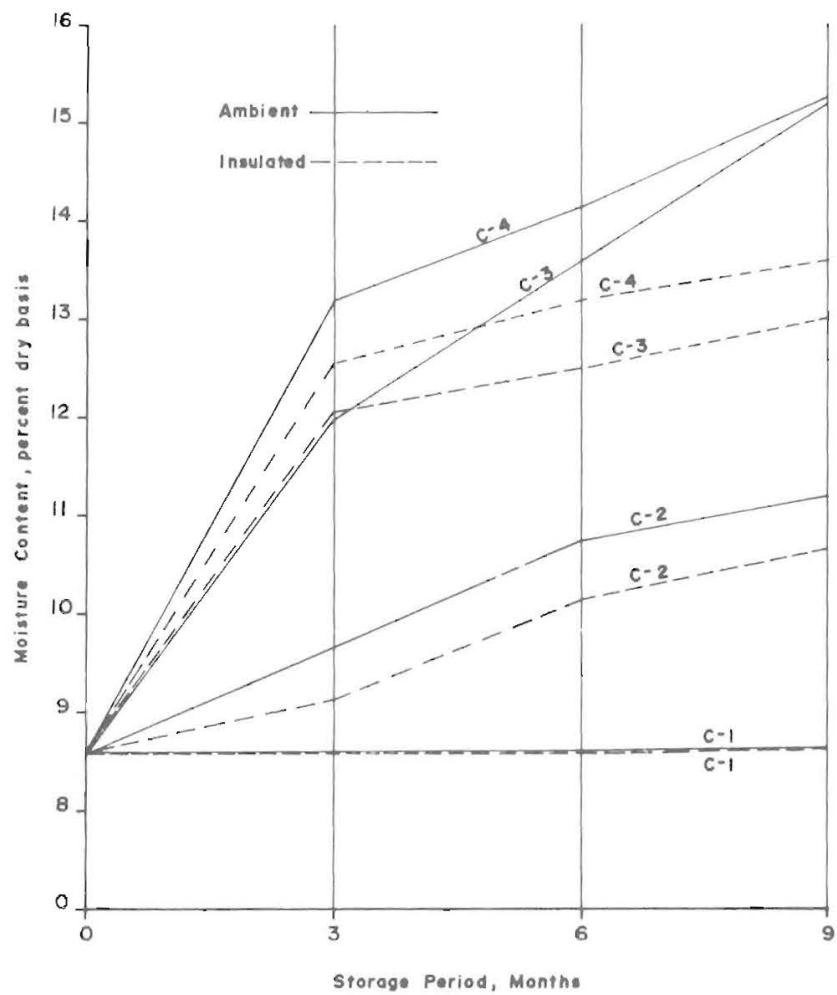

FIG. 5. - Changes in moisture content (dry basis) of Woodworth soybc.m seeds stored for 3,6 , or 9 mo under ambient conditions in sealed metal food cans $\left(C_{1}\right)$; metal cans with plastic lining (not sealed) $\left(\mathrm{C}_{2}\right)$; fertilizer bags with plastic linings $\left(\mathrm{C}_{3}\right)$; and cloth bags $\left(\mathrm{C}_{4}\right)$.

minated $86.6 \%$, and $14.4 \%$ of the nongerminated seeds had B. subtilis associated with them.

Results from both assays showed that, as storage time increased, there was concomitant decrease in germination and an increase in the recovery of B. subtilis (fig. 2). There was a high incidence of nongemninating seeds without microorganisms at the $25^{\circ} \mathrm{C}$ assay, while at $35^{\circ} \mathrm{C}$, there was a high percentage of $B$. subtilis associated with nongerminated seeds. This 
TABLE 1.-The main effects for the factors of location, storage condition, container, seed moisture content, and storage time, and all their possible interactions, for surface-disinfected seeds for the parameters of germination without microorganisms, nongermination without microorganisms, and with Bacillus subtilis, on potato-dextrose agar for 7 days at $25^{\circ} \mathrm{C}$, and germination without microorganisms and nongermination with Bacillus subtilis on cellulose pads for 5 days at $35^{\circ} \mathrm{C}$

\begin{tabular}{|c|c|c|c|c|c|c|}
\hline \multirow{3}{*}{ Source } & \multirow{3}{*}{$\begin{array}{l}\text { Degrees } \\
\quad \text { of } \\
\text { freedom }\end{array}$} & \multicolumn{3}{|c|}{ Potato-dextrose agar } & \multicolumn{2}{|c|}{ Cellulose pads } \\
\hline & & \multirow{2}{*}{$\begin{array}{c}\text { Germination } \\
\text { Without } \\
\text { microorganisms }\end{array}$} & \multicolumn{2}{|c|}{ Nongermination } & \multirow{2}{*}{$\begin{array}{c}\text { Germination } \\
\text { Without } \\
\text { microorganisms }\end{array}$} & \multirow{2}{*}{$\begin{array}{c}\text { Nongermination } \\
\text { With Bacillus } \\
\text { subtilis }\end{array}$} \\
\hline & & & $\begin{array}{l}\text { Without } \\
\text { microorganisms }\end{array}$ & $\begin{array}{l}\text { With Bacillus } \\
\text { subtilis }\end{array}$ & & \\
\hline$A^{!}$ & 1 & $0.71 \mathrm{NS}^{2}$ & $19.56^{* *}$ & $33.13^{* *}$ & $67.57^{* *}$ & $67.57^{* *}$ \\
\hline $\mathrm{B}$ & 1 & $11.65^{* * 3}$ & $.63 \mathrm{NS}$ & $24.71^{* *}$ & $.21 \mathrm{NS}$ & $.21 \mathrm{NS}$ \\
\hline $\mathrm{C}$ & 3 & $254.70 * *$ & $140.20^{* *}$ & $9.13^{* *}$ & $83.49 * *$ & $83.49 * *$ \\
\hline D & 2 & $64.21^{* *}$ & $43.03^{* *}$ & $4.00^{* *}$ & $31.85^{* *}$ & $31.85^{* *}$ \\
\hline $\mathrm{E}$ & 2 & $1257.76^{* *}$ & $613.14^{* *}$ & $144.52^{* *}$ & $1768.71^{* *}$ & $1768.71^{* *}$ \\
\hline$A \times B$ & 1. & $1.64 \mathrm{NS}$ & $10.56^{* *}$ & $40.00^{* *}$ & $2.61 \mathrm{NS}$ & $2.61 \mathrm{NS}$ \\
\hline $\mathrm{A} \times \mathrm{C}$ & 3 & $10.78^{* *}$ & $7.27^{* *}$ & $3.76^{*}$ & $41.26^{* *}$ & $41.26^{* * *}$ \\
\hline$A \times D$ & 2 & $.45 \mathrm{NS}$ & $1.56 \mathrm{NS}$ & $8.87^{* *}$ & $11.11^{* *}$ & $11.11^{* *}$ \\
\hline$A \times E$ & 2 & $6.41^{* *}$ & $37.64^{* *}$ & $31.90 * *$ & $94.61^{* *}$ & $94.61^{* *}$ \\
\hline $\mathrm{B} \times \mathrm{C}$ & 3 & $1.22 \mathrm{NS}$ & $1.77 \mathrm{NS}$ & $7.89^{* *}$ & $1.04 \mathrm{NS}$ & $1.04 \mathrm{NS}$ \\
\hline $\mathrm{B} \times \mathrm{D}$ & 2 & $.80 \mathrm{NS}$ & $1.46 \mathrm{NS}$ & $3.82^{*}$ & $.12 \mathrm{NS}$ & $.12 \mathrm{NS}$ \\
\hline $\mathrm{B} \times \mathrm{E}$ & 2 & $9.97 * *$ & $11.29 * *$ & $4.64^{* *}$ & $.35 \mathrm{NS}$ & $.35 \mathrm{NS}$ \\
\hline $\mathrm{C} \times \mathrm{D}$ & 6 & $12.72^{* *}$ & $7.53^{* *}$ & $2.77^{*}$ & $6.13^{* *}$ & $6.13^{* *}$ \\
\hline $\mathrm{C} \times \mathrm{E}$ & 6 & $66.79 * *$ & $38.64 * *$ & $6.01^{* * *}$ & $27.96^{* *}$ & $27.96^{* *}$ \\
\hline $\mathrm{D} \times \mathrm{E}$ & 4 & $14.57^{* *}$ & $6.85^{* *}$ & $2.80^{*}$ & $11.86^{* *}$ & $11.86^{* * *}$ \\
\hline $\mathrm{A} \times \mathrm{B} \times \mathrm{C}$ & 3 & $.30 \mathrm{NS}$ & $1.28 \mathrm{NS}$ & $4.97^{* *}$ & $.24 \mathrm{NS}$ & $.24 \mathrm{NS}$ \\
\hline$A \times B \times D$ & 2 & $1.79 \mathrm{NS}$ & $2.66 \mathrm{NS}$ & $.36 \mathrm{NS}$ & $4.00^{*}$ & $4.00^{*}$ \\
\hline $\mathrm{A} \times \mathrm{B} \times \mathrm{E}$ & 2 & $3.39^{*}$ & $42.84^{* *}$ & $47.39^{* *}$ & $.44 \mathrm{NS}$ & $.44 \mathrm{NS}$ \\
\hline $\mathrm{A} \times \mathrm{C} \times \mathrm{D}$ & 6 & $.81 \mathrm{NS}$ & $.86 \mathrm{NS}$ & $1.26 \mathrm{NS}$ & $3.13^{* *}$ & $3.13^{* *}$ \\
\hline $\mathrm{A} \times \mathrm{C} \times \mathrm{E}$ & 6 & $4.12 * *$ & $4.36^{* *}$ & $6.81^{* *}$ & $18.21^{* *}$ & $18.21^{* *}$ \\
\hline
\end{tabular}




\begin{tabular}{|c|c|c|c|c|c|c|}
\hline $\mathrm{A} \times \mathrm{D} \times \mathrm{E}$ & 4 & $2.90^{*}$ & $1.22 \mathrm{NS}$ & $6.52^{* *}$ & $6.61^{* *}$ & $6.61^{* *}$ \\
\hline $\mathrm{B} \times \mathrm{C} \times \mathrm{D}$ & 6 & $2.28^{*}$ & $3.84^{* *}$ & $5.64^{* *}$ & $.52 \mathrm{NS}$ & $.52 \mathrm{NS}$ \\
\hline $\mathrm{B} \times \mathrm{C} \times \mathrm{E}$ & 6 & $.95 \mathrm{NS}$ & $6.38^{* *}$ & $9.34^{* *}$ & $.82 \mathrm{NS}$ & $.82 \mathrm{NS}$ \\
\hline $\mathrm{B} \times \mathrm{D} \times \mathrm{E}$ & 4 & $1.91 \mathrm{NS}$ & $2.16 \mathrm{NS}$ & $4.81^{* *}$ & $.21 \mathrm{NS}$ & $.21 \mathrm{NS}$ \\
\hline $\mathrm{C} \times \mathrm{D} \times \mathrm{E}$ & 12 & $7.31^{* *}$ & $2.81^{* *}$ & $2.87^{* *}$ & $3.97^{* *}$ & $3.97^{* *}$ \\
\hline $\mathrm{A} \times \mathrm{B} \times \mathrm{C} \times \mathrm{D}$ & 6 & $.82 \mathrm{NS}$ & $1.81 \mathrm{NS}$ & $3.92^{* *}$ & $.47 \mathrm{NS}$ & $.47 \mathrm{NS}$ \\
\hline $\mathrm{A} \times \mathrm{B} \times \mathrm{C} \times \mathrm{E}$ & 6 & $1.20 \mathrm{NS}$ & $4.20^{* *}$ & $9.39 * *$ & $2.23^{*}$ & $2.23^{*}$ \\
\hline $\mathrm{A} \times \mathrm{B} \times \mathrm{D} \times \mathrm{E}$ & 4 & $1.11 \mathrm{NS}$ & $1.52 \mathrm{NS}$ & $.65 \mathrm{NS}$ & $.63 \mathrm{NS}$ & $.63 \mathrm{NS}$ \\
\hline $\mathrm{A} \times \mathrm{C} \times \mathrm{D} \times \mathrm{E}$ & 12 & $1.61 \mathrm{NS}$ & $.81 \mathrm{NS}$ & $2.68^{* *}$ & $2.29 * *$ & $2.29^{* *}$ \\
\hline $\mathrm{B} \times \mathrm{C} \times \mathrm{D} \times \mathrm{E}$ & 12 & $2.58^{* *}$ & $2.99 * *$ & $4.92^{* *}$ & $.65 \mathrm{NS}$ & $.65 \mathrm{NS}$ \\
\hline $\mathrm{A} \times \mathrm{B} \times \mathrm{C} \times \mathrm{D} \times \mathrm{E}$ & 12 & 1.11. NS & $3.31^{* *}$ & $4.70^{* *}$ & $.89 \mathrm{NS}$ & $.89 \mathrm{NS}$ \\
\hline
\end{tabular}

${ }^{1} \mathrm{~A}=$ locations, $\mathrm{B}=$ storage conditions, $\mathrm{C}=$ containers, $\mathrm{D}=$ initial moisture contents, and $\mathrm{E}=$ storage periods (time).

${ }^{2}$ Calculated F values.

${ }^{3 * *}=$ Significant at the $1 \%$ level; ${ }^{*}=$ significant at the $5 \%$ level; NS $=$ nonsignificant 
illustrates the selectivity of the two assay temperatures for the development of the bacterium on soybean seeds.

Seeds with an initial moisture level of $8.6 \%$ had the highest percentage germination and lowest percentage of occurrence of B. subtilis, while those with an initial moisture level of $12.5 \%$ had the lowest percentage germination and the highest percentage of occurrence of $B$. subtilis at both assay temperatures (fig. 3 ). More nongerminated seeds contained microorganisms at $35^{\circ} \mathrm{C}$ than at $25^{\circ} \mathrm{C}$ assay.

Germination decreased and the percentage of B. subtilis increased as the container varied from sealed metal food cans to nonsealed metal food cans with plastic lining, fertilizer bag with plastic lining, and cloth bag, in that order (fig. 4).

Changes in germination and population of B. subtilis for various storage conditions investigated in this study seemed strongly associated with the changes in moisture content while in storage (fig. 5).

Location, containers, and initial moisture level of seeds were major factors which most influenced final seed quality. Interactions between these factors were measurable. The $F$ values for the main effects of all experimental factors and their interactions are summarized in table 1.

\section{DISCUSSION}

This is the first report on the role of microorganisms in the deterioration of soybean seeds stored under tropical conditions. With the beginning of soybean production in the tropics, the development of proper storage conditions for the crop is an important consideration. The results show that microorganisms, particularly B. subtilis, can cause serious problems (figs. 2, 3, and 4).

Schiller et al. (11), Tedia (13), and Tenne et al. (16) reported similar results from studies in the temperate regions. $B$. subtilis is seed-borne in soybeans $(15,16)$, occurring in association with roots, stems, and leaves of soybean cultivars sensitive to high concentrations of phosphorus (4). It has been reported associated with soybean seeds in India (12) and six other countries, including the United States (16).

Low moisture content is a key factor in maintaining seed viability in storage. The results suggest that the ability of the container to minimize moisture gain during storage is as important as low initial moisture content in preserving seed viability in the tropics. Low moisture contents are unfavorable for the growth of microorganisms. Unprotected seeds absorb moisture from the air until equilibrium is reached. This is especially critical in the tropics where wide daily fluctuations of relative humidity occur, ranging from as low as $60 \%$ in the afternoon to a high of nearly $100 \%$ in the early morning. The key to preserving seed viability under the humid conditions in the tropics suggested by the results of this 
study is to dry the seed to about $8.6 \%$ moisture content dry basis and store it in containers which minimize moisture gain from the atmosphere while the seed is in storage. These studies show that the best procedure for soybean seed was storage in sealed metal cans at $8.6 \%$ moisture. Similar results were reported by Tedia (13).

\section{RESUMEN}

En las condiciones tropicales de Puerto Rico, en dos campos de la Universidad de Puerto Rico (Mayagüez e Isabela) se almacenaron semillas de sojas de la variedad Woodworth. Se usaron cuatro tipos de envases a tres niveles de humedad en un diseño factorial distribuido completamente al azar. De todos los factores, la germinación fue el que más disminuyó con el tiempo. La germinación disminuyó según aumentó el tiempo de almacenamiento; al mismo tiempo aumentó la incidencia del Bacillus subtilis. A los 9 meses, las semillas con un contenido de humedad inicial de $8.6 \%$ tuvieron una germinación mayor y una incidencia menor de organismos portados por la semilla que las almacenadas con 10.7 y $12.5 \%$ de humedad. Semillas almacenadas en latas selladas de 200 gramos retuvieron la germinación por más tiempo que las almacenadas en latas sin sellar con revestimiento plástico o en sacos de tela. Semillas almacenadas en sacos de tela tuvieron una incidencia mayor de $B$. subtilis que las de otros tipos de envases. Para cualquiera de los efectos o interacciones mayores, dependiendo de la característica medida, hubo o no hubo diferencias significativas entre las localizaciones.

\section{LITERATURE CITED}

1. Baciu, D., 1972. Effect of storage conditions on the quality of soybean seed. Inst. Cercatari Cereale Plante Teh. Fundulea C. Amelior. Plant. Probl. Genet. Teor. Apl. 38: 247-57. Field Crop Abstr. 4: 1822.

2. Buchanan, R. E., and Gibbons, W. E., Ed, 1974. Bergey's Manual of Determinative Bacteriology. 8th ed. Williams and Wilkens Co., Baltimore, Md.

3. Dorworth, C. F., and Christensen, C. M., 1968. Influence of moisture, temperature and storage time upon changes in fungus flora, germinability and fat acidity values, Phytopathology 58: 1457.

4. Dunleavy, J., Kunkel, J. F., and Hanway, J. J., 1966. High populations of Bacillus subtilis associated with phosphorus toxicity in soybeans, Phytopathology 56: 83-7.

5. Ellis, M. A., Tenne, F. D., and Sinclair, J. B. 1976. Effects of antibiotics and high temperature storage on decay of soybean seed by Bacillus subtilis. Seed Sci. Technol. (in press).

6. Fernando, M., and Stevenson, G., 1952. Studies in the physiology of parasitism: XVI. Effects of conditions of potato tissue, as modified by temperatures and water content, upon attack by certain organisms and their pectinase enzymes, Ann. Bot. 16: 103-14.

7. Grabe, D. F., 1965. Storage of soybean for seed. Soybean Digest 26(1): 14-6.

8. Harrington, J. F., 1973. Packaging seed for storage and shipment, Seed Sci. Technol. 3: 701-9.

9. Kennedy, B. W., 1964. Moisture content, mold invasion and viability of stored soybeans, Phytopathology 54: 771-4.

10. Ramstad, P. E., and Geddes, W. F., 1942. Respiration and storage behavior of soybeans, Minn. Agric. Exp. Stn. Tech. Bull. 156.

11. Schiller, C. T., Ellis, M. A., Tenne, F. D., and Sinclair, J. B., 1976. Effect of Bacillus subtilis on soybean seed decay, germination and stand inhibition, Plant Dis. Rep. 61: 213-17.

12. Singh, O. V., Agarwal, V. K., and Nene, Y. L., 1973. Seed health studies in soybean raised in the Nainital Tarai, India Phytopathol. 26: 260-7.

13. Tedia, M. D., 1976. Effect of storage conditions and environment during maturation of soybean seed quality and crop performance, Ph.D. thesis, Univ. Ill., Urbana, 164 p. 
14. Tenne, F. D., 1977. The relatinnship of seed-borne fungi and Bacillus subtilis with soybean seeds under ter.pperate and tropical conditions, Ph.D. thesis, Univ. Ill., Urbana, $98 \mathrm{p}$.

15. — Foor, S. R., and Sinclair, J. B., 1976. Association of Bacillus subtilis with soybean seeds, Seed. Sci. Technol. 5. In press.

16. - Mengistu, A., and Sinclair, J. B., 1975. Occurrence and identification of Bacillus subtilis associated with soybean seed from six geographical regions, Proc. Am. Phytopathol. Soc. 2: 91, (Abstr.).

17. Trevet, I. W., 1945. The influence of fungi in storage on seed viability and seedling vigor of soybeans, Phytopathology 35: 3-15. 